\title{
Ortiz, M. L. (2019). Con los vientos del Cordobazo. Los trabajado- res clasistas en tiempos de violencia y represión. Córdoba, Argentina: Universidad Nacional de Córdoba. 460 pp.
}

Alicia Servetto $^{1}$

Con los vientos del Cordobazo, ilustrativa metáfora para titular un libro dedicado a lo que pasó después del 29 de mayo de 1969. Alude a ese acontecimiento, pero también a sus efectos, lo que ocasionó el Cordobazo, lo que pasó y lo que arrastró. La palabra viento nos remite indefectiblemente a la idea de movimiento, de corriente, de flujo, pero igualmente a fuerza y a su capacidad de erosión. Eolo era el dios griego de los vientos, tan temido como respetado.

A 50 años del Cordobazo, volviendo la mirada hacia atrás en el tiempo ¿acaso no estamos haciendo referencia a todo eso? El libro de María Laura Ortiz lo expresa claramente «El Cordobazo fue el estallido popular que abrió una nueva etapa sociopolítica y que marcó fuertemente la cultura política del momento. Luego de aquella insurrección la ciudad ya no volvió a ser la misma. Con los vientos del Cordobazo, después, todo fue distinto».

¿Que provocaron esos vientos? Los vientos del Cordobazo, abrieron varios procesos al mismo tiempo: liquidación de la dictadura de la Revolución Argentina (1966-1973), inauguración de una ola de movilización social, surgimiento de un sindicalismo alternativo -el clasismo-desarrollo de las organizaciones revolucionarias y radicalización ideológica de vastos sectores de la sociedad argentina.

La segunda parte del título no es menos ilustrativa: Los trabajadores clasistas en tiempos de violencia y represión. En efecto, lo que sucedió después fue otra revuelta más radicalizada, conocida como el Viborazo protagonizada por el sindicalismo revolucionario -o clasismo- con presencia de las organizaciones de la izquierda revolucionaria.

¿Qué fue el clasismo? ¿Por qué surgió? ¿Cómo se explica el origen del clasismo? ¿Qué condiciones habilitaron el surgimiento del sindicalismo de base revolucionaria en Córdoba? Estas preguntas recorren el libro y son analizadas a través de un exhaustivo uso de fuentes escritas y orales, enhebrando los hilos de un período denso, complejo, de notable potencialidad que no cae en la tentación del mito ni en la de las explicaciones complacientes.

El libro puede leerse en tres claves analíticas:

a) La conflictividad social en torno a la distribución del ingreso y al control de los medios de producción en un contexto de crisis de dominación social bajo un gobierno burocrático autoritario para usar la calificación

\footnotetext{
${ }^{1}$ Universidad Nacional de Córdoba. Contacto: aliciaservetto@unc.edu.ar
} 
de Guillermo O'Donnel. A esta crisis de la dominación social se le anteponía una crisis de acumulación en donde las acciones de las clases subordinadas eran percibidas por las clases dominantes como obstáculos para la economía. La conflictividad social era una forma de impugnación a esa orden social y político que se consideraba inmutable e inexpugnable.

b) La politización y la radicalización ideológica. Se desarrolló un tipo de sindicalismo que difería de los moldes organizativos e ideológicos de la clase trabajadora en la que predominaba una fuerte identidad peronista. Aún con variaciones, el sindicalismo clasista se basó en una serie de postulados que lo hacían diferente de la llamada entonces burocracia sindical: autonomía política, asambleísmo de base, ideología marxista de lucha de clases, abolición del capitalismo y establecimiento del socialismo en la Argentina.

c) La represión. El Estado de sitio, la guerra antisubversiva, los golpes militares, las dictaduras, en cualquiera de sus formas, cumplían, en definitiva, un mismo objetivo: transformar las bases económicas y sociales del Estado y re-fundar el pacto de dominación capitalista. Este objetivo sólo era factible a partir de una rígida política de desmovilización y disciplinamiento de los actores sociales «insubordinados».

Con los vientos del Cordobazo es la historia de una experiencia sindical, radicalizada, de izquierda y revolucionaria. Atravesó los últimos años de la dictadura de la Revolución Argentina (19661973), el auge de las luchas populares y de las organizaciones de la izquierda revolucionaria, la lucha armada, el tercer gobierno peronista (1973-1976) y finalmente el repliegue y desarticulación con la última dictadura militar (19761983).

El libro es una invitación atractiva para sumirse en los agitados y tumultuosos años 60 y 70 y revisitar una vez más las distintas facetas de aquella Córdoba combativa, movilizada, revolucionaria, pero también reaccionaria, militarizada y represiva. En las páginas de este libro encontrará parte de esta historia, tan necesaria como imprescindible. 